\title{
TEORI ULAMA HADIS TENTANG SYARTH SAHIH AL-BUKHARI
}

\author{
M. Syukrillah \\ Sekolah Tinggi Ilmu Al-Qur'an (STIQ) Al-Husayni Kota Bima \\ Dekuyun1983@gmail.com
}

\begin{abstract}
Abstrak
Karya al-Bukhari berupa al-Jami' al-Shahih atau yang dikenal dengan Sahih al-Bukhari merupakan masterpiece dalam bidang hadis. Sebagai penyusun kitab tersebut, Al-Bukhari menjamin validitas hadis-hadis di dalamnya tanpa menjelaskan kriteria atau syarat kesahihannya. Apresiasi yang tinggi kepada kitab Sahih al-Bukhari telah memancing minat para peneliti hadis untuk meneliti lebih jauh terhadap konsep dan syarat validitas hadis menurut penulis kitab tersebut. Di antara ulama yang meneliti dan merumuskan tentang syarat sahih al-Bukhari adalah al-Hakim (w. 405 H), Muhammad Thahir al-Maqdisy (w. 507 H), al-Hazimy (w. 584 $\mathrm{H})$, an-Nawawy (w. $676 \mathrm{H})$. Rumusan istilah syarth al-Bukhari ternyata masih merupakan sesuatu yang kontroversial dan menjadi diskursus ulama hadis dari masa ke masa.
\end{abstract}

Kata Kunci: Syarat Sahih al-Bukhari, Ulama Hadis, Sahih al-Bukhari

\section{Pendahuluan}

$\mathrm{M}$

ayoritas ulama hadis meyakini bahwa al-Bukhari adalah orang yang pertama kali menyusun kitab hadis yang secara khusus menghimpun hadis-hadis yang berkualitas sahih saja. ${ }^{1}$ Mereka berpendapat bahwa hadis-hadis dalam Kitab Sahih al-Bukhari berkualitas sahih, bahkan

kitabnya dinyatakan sebagai kitab paling sahih setelah Al-Quran. ${ }^{2}$ Pengakuan validitas hadis-hadis di dalam kitab tersebut bahkan dimulai sejak masa hidup alBukhari sendiri saat ia menyodorkan karyanya tersebut kepada pada ulama hadis senior di zamannya seperti Ahmad bin Hanbal, Yahya bin Ma'in, Ali al-Madiny, dan lain-lain. Mereka kemudian menyetujui pensahihan al-Bukhari atas seluruh hadis dalam Shahih al-Bukhari kecuali empat hadis saja. ${ }^{3}$ Al-Bukhari diakui

${ }^{1}$ Ibrahim bin Musa bin Ayub al-Abnasy. Asy-Syadz al-Fiyah min " Ulumil Hadis. Tahqiq: Shalah Fathi Hilal (Riyadh: Maktabah Rusyd, Cet. 1: 1418 H/1998 M) Juz 1, 82. Jalaluddin alSuyuthi, Tadrib al-Rawy fi Syarh Taqrib an-Nawawy, vol. 1, ed. Abu Mu'adz Thariq bin 'Audhillah bin Muhammad (Riyadh: Dar al-'Ashimah, 1423 H), 117. Ibnu Shalah, Abu 'Amr Utsman, 'Ulum al-Hadith (Muqaddimah Ibn Al-Salah), ed. Nuruddin 'Itr (Beirut: Dar al-Fikr, cet. 3, 1418 H), 17. Nuruddin 'itr, Manh\}aj al-Naqd fi 'Ulum al-h\}adith (Damaskus : Dar al-Fikr, Cet. 3, 1418 H/1997 M), 251. Al-Sakhawy. Fath al-Mughits Syarh Alfiyah al-H\{adith. Tahqiq: 'Abdul Karim al-Khudhair dan Muhammad bin Abdullah Alu Fuhaid (Saudi: Maktabah Ushul al-Salaf, Cet.1, 1418 H), 46

${ }^{2}$ Yahya bin Syarf an-Nawawi. Muqaddimah Syarh al-Nawawi 'ala Shahih Muslim, Juz 1 (Kairo: Al-Matba'ah al-Mishriyah bi al-Azhar, Cet. 1, 1347 H/1929 M), 14, Ibnu Shalah. 'Ulum al-Hadith...., 28, Ibnu Katsir, Al-Ba'its al-Hatsis Syarh Ikhtishar Ulum al-Hadits, ed. Syaikh Ahmad Syakir (Beirut: Dar al-Kutub al-'Ilmiyah, tanpa tahun), 34

${ }^{3}$ Ibnu Hajar, Hadyu al-Sary Muqaddimah Fath al-Bary, ed. Syaikh 'Abd al-Qadir Syaibah al-Hamd (Riyadh: Maktabah al-Malik Fahd al-Wat\{oniyyah, cet. 1, 1421 H/ 2001 M), 9 
memakai standard tinggi dalam seleksi hadis sahih yang dicantumkannya dalam kitab al-Jami' al-Shahih. ${ }^{4}$ Namun sayangnya, al-Bukhari sendiri tidak menjelaskan tentang kriteria, standar atau syarat kesahihan hadis-hadisnya baik dalam kitab al-Jami' al-Shahih maupun kitab-kitabnya yang lain. Al-Bukhari hanya menegaskan:

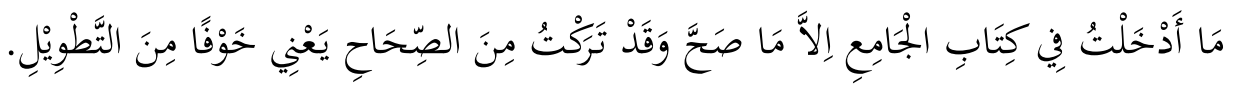

"Tidaklah hadis yang aku cantumkan dalam Kitab al-Jami' melainkan yang shahih, dan aku tinggalkan hadis-hadis lain yang sahih karena khawatir (pembahasannya) terlalu panjang (kitab menjadi terlalu tebal)."

Hal inilah yang memancing minat para peneliti hadis sejak dulu untuk mencoba merumuskannya. Perumusan syarat sahih al-Bukhari dan manhjaj-nya dalam pencantuman hadis-hadisnya dilakukan dengan metode induktif (alIstiqra 'iy) yaitu meneliti hadis-hadis al-Jami' al-Shahih untuk mendapatkan kesimpulan umum tentang syarat-syaratnya. ${ }^{6}$ Di antara ulama yang membahas dan merumuskan tentang syarat sahih al-Bukhari adalah al-Hakim (w. $405 \mathrm{H}$ ), Muhammad Thahir al-Maqdisy (w. 507 H), al-Hazimy (w. 584 H), dan alNawawy (w. 676 H).

\section{Diskursus tentang Syarth al-Bukhari}

Istilah syarth al-Bukhari belumlah populer sebelum zaman al-Bukhari, atau pada masa hidupnya, bahkan beberapa waktu setelah zamannya. Abu Mu'adz Thariq bin 'Audhillah berpendapat bahwa orang yang pertama kali memperkenalkan istilah ini adalah al-Daraquthny (w. $385 \mathrm{H}$ ) dalam kitabnya alIlzamat. ${ }^{7}$ Dalam kitab tersebut, al-Daraquthny menyebutkan tentang adanya hadishadis yang sebenarnya sesuai dengan syarat al-Bukhari maupun muslim tetapi tidak dikeluarkan oleh keduanya dalam kitab sahih masing-masing. AlDaraquthny juga mengkritisi hadis-hadis al-Bukhari dalam al-Jami' al-Shahih yang tidak sesuai dengan syarat tersebut karena adanya 'illah. ${ }^{8}$

${ }^{4} \mathrm{Hal}$ ini dapat dilihat dalam penjelasan para ulama hadis dalam merangking peringkat/derajat kesahihan hadis berdasarkan syarat kesahihannya. Lihat Ibnu Salah, Mukaddimah.., 27-28, Al-Suyuthi. Tadrib al-Rawy fi Syarh Taqrib an-Nawawy, Vol.1, 168-9, Ibnu Hajar, al-Nukat 'alaKitab Ibn S\{alah, vol. 1, ed. Dr. Rabi' bin Hady 'Umair (Riyadh : DaralRayah, cet. 3, 1415 H/1994 M), 364, Al-Sakhawy. Fath al-Mughits Syarh Alfiyah al-Hadits, Vol. $1,75-91$.

${ }^{5}$ Syamsuddin Muhammad bin Ahmad Adz-Dzahaby. Siyar A'lam Nubala', Vol. 10 (Beirut: Muassasah al-Risalah, cet. 9, 1413 H/1993 M), 96 dan Vol. 12, 402

${ }^{6}$ Shalih Muhammad bin Shalih al-Syahir. Al-Ahadits allati yuriduha al-Imam alBukhari fi Tarajim al-Abwab wala yasrah bi kauniha ahadits, wa laisat 'ala syartihi (Tesis magister, Kuliyah Dakwah wa Ushuluddin, Qism Dirasat al-Ulya, program studi al-Kitab wa As-Sunah, Jami'ah Ummu al-Qura', 1421 H, tidak dicetak), 81

${ }^{7}$ Komentar atas Kitab Tadrib ar-Rawy, vol. 1, 179

${ }^{8}$ Al-Daruquthny, al-Ilzamat wa al-Tatabbu', ed. Muqbil bin Hady al-Wad'y (Beirut: Dar al-Kutub al-'Ilmiyah, cet. 2, 1405 H/1985 M), 56 
Sementara al-Hakim (w. $405 \mathrm{H}$ ) adalah ulama hadis yang mempopulerkan istilah 'ala syarth al-Bukhari, 'ala syarth Muslim, 'alasyart al-Bukhari wa Muslim, atau 'alasyartihima. Istilah tersebut banyak dipakai dalam kitabnya alMustadrak 'ala al-Shahihain". 9 Al-Hakim, di samping sebagai ulama hadis yang mempopulerkan istilah ini, beliau juga terhitung sebagai pelopor di dalam perumusan konsep syarat sahih menurut al-Bukhari dan Muslim. ${ }^{10}$ Berikut paparan tentang teori syarat sahih al-Bukhari tersebut dalam berbagai pendapat dan perspektif serta analisisnya:

\section{Teori Al-Hakim (w. 405 H) dan Analisa Kritis Terhadapnya}

Menurut al-Hakim syarat shahih al-Bukhari ada pada perawi-perawi yang digunakan periwayatannya. Dalam Kitab al-Madkhal, al-Hakim menyebutkan bahwa tingkatan pertama dari level hadis sahih yang dipilih oleh al-Bukhari dan Muslim adalah hadis yang diriwayatkan dari Rasulullah SAW oleh urutan para perawi yang bersambung yang memenuhi kriteria sbb: (1) Perawi dari shahabat yang tidak majhul karena diriwayatkan oleh dua orang tabi'in yang adil, (2) Perawi generasi tabi'in yang terkenal meriwayatkan hadis dari sahabat dan dia memiliki minimal dua orang perawi berikutnya yang thiqah. (3) Perawi dari generasi atba' at-tabi'in yang hafizh dan mutqin dalam meriwayatkan hadis. Perawi tersebut memiliki murid-murid dari thabaqah keempat (atba' atba' tabi'in), (4) Guru al-Bukhari atau Muslim yang hafizh dan masyhur dengan sifat 'adalah dalam periwayatannya. Kemudian beredar di kalangan para ahli hadis dengan pengakuan maqbul sampai masa kita sebagai syahadah (persaksian kredibitas) atas syahadah. ${ }^{11}$ Di samping itu, dalam mukaddimah kitabnya alMustadrak 'ala Shahihain, al-Hakim berpendapat bahwa al-Bukhari demikian juga Muslim tidak mensyaratkan hadis-hadis harus bebas dari 'illah. Pendapat alHakim ini termanifestasikan dalam pilihan-pilihan hadis dalam kitab tersebut yang cukup banyak mengandung illat, padahal secara eksplisit al-Hakim mengklaim bahwa syarat kitabnya adalah menghimpun hadis-hadis yang riwayatnya semisal dengan sanad-sanad yang dipakai hujjah oleh al-Bukhari dan Muslim. ${ }^{12}$

Dengan demikian, bisa disimpulkan pandangan al-Hakim tentang syarat al-Bukhari; (1) mensyaratkan faktor jumlah perawi sebagai syarat sahih,. Al-

${ }^{9}$ Lihat Muhammad bin Abdillah Al-Hakim al-Naisabury, al-Mustadrak 'ala Sahihain, Vol. 1, ed. Muqbil bin Hadi al-Wad'iy (Kairo: Dar al-Haramain, Cet. 1, 1417 H/1997 M), 41. Penggunaan istilah-istilah tersebut oleh al-Hakim dalam mengklaim tingkat keSahihan hadishadis dalam al-Mustadrak banyak mengundang kritikan bahkan protes pedas dari ulama hadis lain. Hal ini karena terbukti al-Hakim banyak mengklaim suatu hadis sebagai hadis sahih.

${ }^{10}$ Sebelumnya ada al-Qadhi 'Iyadh dan berikutnya ulama yang semasa dengan al-Hakim, yaitu Ibnu Mandah menyebut tentang syarat al-Bukhari ini.

${ }^{111}$ Al-Hakim. Al-Madkhal ila Kitab al-Iklil. Ed. DR. Fuad Abdul Mun'im Ahmad. (Dar Dakwah : Iskandariyah), 186

${ }^{12}$ Al-Hakim. Al-Hakim al-Naisabury, al-Mustadrak 'ala al-Sahihain, Vol. 1, ed. Muqbil bin Hady al-Wad'y (Kairo: Dar al-Haromain, cet. 1, 1417 H/1997 M), 2-3. 
Hakim menolak adanya perawi wuhdan ${ }^{13}$ dalam Shahih al-Bukhari. ${ }^{14}$ (2) alBukhari dan Muslim tidak mensyaratkan hadis-hadisnya bebas dari 'illah ('adam al-illah). Pendapat al-Hakim tersebut mengundang pro-kontra di kalangan ulama hadis. Ulama yang sezaman dengan al-Hakim dan sepakat dengan pendapat alHakim tersebut adalah Ibn Mandah dan al-Baihaqy. ${ }^{15}$ Bahkan, menurut Abu alFadl al-Maqdisi, al-hafizh Abu Abdillah bin Muhammad bin Ishaq bin Mandah (W. $395 \mathrm{H}$ ) telah mendahului al-Hakim dalam mengemukakan konsep syarat kuantitas tersebut. ${ }^{16}$

Namun demikian, pendapat al-Hakim tersebut dikritik keras oleh sebagian ulama hadis. Mereka menolak adanya pensyaratan jumlah perawi sebagai syarat kesahihan al-Bukhari dan Muslim. ${ }^{17}$ Terkait syarat jumlah perawi ini, al-Nawawi berkomentar; "Bukan demikian syarat al-Bukhari dan Muslim karena keduanya juga mengeluarkan hadis-hadis yang hanya memiliki sanad tunggal (ahad gharib), misalnya hadis "Innama al-a'mal bi al-niyat". Hadis dengan kondisi sanad yang semisal dengan ini cukup banyak dalam alShahihain. ${ }^{18}$

Demikian pula, Abu al-Fadhl Muhammad bin Thahir al-Maqdisi (w. 507 H) menolak rumusan al-Hakim tersebut. Al-Maqdisi bahkan menilai bahwa alHakim belum melakukan analisis dan penelitian yang cukup untuk sampai kepada hasil akhir kesimpulan yang benar dan meyakinkan. Rumusan tersebut hanya lahir dari asumsi atau praduga. Karena kenyataan hadis-hadis dalam al-Shahih\}ain

${ }^{13}$ Perawi wuhdan adalah para perawi yang masing-masing hanya memiliki satu orang (murid) yang meriwayatkan hadis dari mereka. Pembahasan ini terkait dengan masalah majhul al-'ain. Al-Hakim menyatakan bahwa al-Bukhari juga Muslim tidak mengeluarkan hadis dari para perawi semacam ini, tetapi jumhur 'ulama menyatakan banyak hadis dalam as-Sahihain dari al-wuhdan di tabaqat shahabat. Lihat Mahmud at-Thahhan. Taisir Mustalah al-Hadith, (Iskandariyah: Markaz al-Huda li ad-Dirasat, $1415 \mathrm{H}$ ), 163

${ }^{14}$ Ada kesenjangan (gap) antara teori al-Hakim tentang syarat al-Bukhari-Muslim dengan praktek al-Hakim dalam aplikasi penilaian hadis atas syarat itu dalam kitabnya yang diberi judul "al-Mustadrak 'ala Sah\}ihain". Secara teori, al-Hakim merumuskan secara ketat syarat Sahih alBukhari.Namun dalam tataran aplikasi rumusan itu tidak sepenuhnya diaplikasikan ketika menyusun kitab al-Mustadrak ala Sahihain. Dalam penilaian hadis yang diklaimnya sebagai 'ala syarth al-syaikhani, atau 'ala syarth al-Bukhari, atau 'ala syarth Muslim justru bersikap tasaahul (longgar) dalam menghukumi keSahihan hadis.

${ }^{15}$ Abubakar al-Kafy, Manhaj al-Imam al-Bukhary fi Tashih al-Ahadith wa Ta'liliha min Khilal al-Jami' al-Sahih (Beirut: Dar Ibn Hazm, cet. 1, 1421 H/2000 H), 118

16 Abu al-Fad \}1 Muhammad Tahir al-Maqdisy, Syurut al-Aimmah al-Sittah wa Yalihi Syurut al-Aimmah al-Khomsah karya al-Hafiz Abubakar Musa al-Hazimy (Beirut: Dar al-Kutub al-'Ilmiyah, cet. 1, $1405 \mathrm{H} / 1984 \mathrm{M}$ )

${ }_{17}$ Muhammad bin Isma'il al-Amir Al-Son'any, Tawdih al-Afkar li Ma'any Tanqih alAnzar, ed. Muhammad Muhyidin 'Abd al-Hamid (al-Madinah al-Munawwarah: al-Maktabah alSalafiyyah, ttt), 22-24. Ibnu Hajar. Hadyu Sari...., 11

${ }^{18}$ Hadis pembuka S $\}$ ahih al-Bukhari dan penutup Sahih\} al-Bukhari adalah hadis ahad. Hadis pertama atau pembuka Sah\}ih al-Bukhari adalah "innamal a'malu bin niyat" yang hanya mempunyai satu jalur sanad (ahad gharib) yaitu Dari Muhammad bin Ibrahim at-Taimy dari AlQamah bin Waqqash al-Laitsi dari Umar bin al-Khattab. Sementara hadis terakhir penutupnya adalah "Kalimatani habibataani ilar rahman khafifatani 'alal lisan" juga adalah hadis ahad gharib yaitu dari Muhammad bin Fudhail dari 'Umaarah bin al-Qa'qa' dari Abi Zur'ah dari Abi Hurairah. 
berbeda dengan rumusan itu. Al-Maqdisi kemudian menyebutkan contoh-contoh hadis dimaksud. ${ }^{19}$ Senada dengan hal itu al-Hazimy (w. $584 \mathrm{H}$ ) juga menolak rumusan al-Hakim dengan membuktikan bahwa dalam riwayat al-Bukhari dan Muslim terdapat riwayat al-gharaib karena sebagian perawinya tafarrud (menyendiri) dalam periwayatannya.

Di sisi lain, beberapa ulama hadis membela pendapat al-Hakim dan mencoba mendudukan pendapat al-Hakim. Ibn al-Atsir berpendapat bahwa alHakim tidak bermaksud seperti yang dipahami oleh al-Maqdisi dan al-Hazimy. Tetapi maksud al-Hakim adalah bahwa masing-masing shahabat memiliki dua orang perawi yang pernah meriwayatkan hadis darinya. Walaupun hadis itu termasuk hujjah (yuhtajju bihi) dalam al-Shahihain tidak memiliki perawi kecuali satu saja. ${ }^{20}$ Jalaluddin as-Suyuthi menafsirkan bahwa maksud al-Hakim yaitu semua perawi yang memiliki riwayat hadis dalam al-Shahihain adalah perawi yang dikenal (ma'ruf) dan bebas dari status jahalah (tidak dikenal ulama hadis) karena adanya dua atau lebih perawi lain yang meriwayatkan hadis darinya. Atau dengan kata lain, semua perawi Al-Bukhari memiliki minimal dua orang murid yang meriwayatkan hadis darinya sehingga ia tidak dinilai sebagai perawi majhul. Jadi, menurut as-Suyuthi, bukanlah maksud al-Hakim menetapkan bahwa tiap hadis dalam al-Shahihain telah diriwayatkan oleh dua orang perawi, kemudian dari tiap orang itu, masing-masing meriwayatkan kepada dua perawi berikutnya.

Namun demikian, pembelaan tersebut masih menyisakan masalah karena pada level (thabaqah) perawi sahabat ada beberapa perawi yang berstatus wuhdan. Di antaranya, al-Bukhari mencantumkan hadis Qais bin Abi Hazim dari Mirdas al-Aslamy RA, padahal tidak ada seorang pun yang meriwayatkan hadis dari Mirdas selain Qais. ${ }^{21}$ Demikian pula al-Bukhari mengeluarkan hadis alHasan al-Bashri dari 'Amr bin Taghlib RA, padahal tidak ada yang meriwayatkan hadis 'Amr selain al-Hasan al-Bashri. ${ }^{22}$ Dalam penelitian Abubakar al-Kafy ada sepuluh orang shahabat yang termasuk wuhdan (hanya mempunyai satu orang murid atau perawi). ${ }^{23}$

Adapun perawi setelah thabaqah sahabat yang berstatus wuhdan dalam sahih al-Bukhari jauh lebih banyak. Di antara data perawi wuhdan tersebut adalah

${ }^{19} \mathrm{Abu}$ Tahir. Syuruth al-Aimmah as-Sittah wa yalihi Syuruth al-Aimmah alKhamsah, 17-18

${ }^{20}$ Lihat dalam Ibnu al-Atsir al-Jazary. Jami' al-Ushul min Ahadits ar-Rasul. Vol. 1, Tahqiq : Abdul Qadir al-Arnauth (Damaskus: ttp, cet 1, 1969 M) , hlm. 92-94

${ }^{21}$ Lihat Al-Bukhari, al-Jami' al-Sahih al-Musnad al-Mukhtasar min Hadith Rasulillah Sallallahu 'alaihi wa Sallam wa Sunanihi wa Ayyamihi, ed. Muhibuddin al-Khatib (Kairo: alMaktabah al-Salafiyah, cet. 1, 1400 H) Kitab al-Riqaq, Bab Dzihab al-Slihin hadis no. 6434 juz 11 hal. 256 dan dalam Ibnu Hajar, Fath\} al-Bary, vol. 7, ed. Syaikh 'Abd al-Qadir Syaibah alHamd (Riyadh: Maktabah al-Malik Fahd al-Wat \}oniyyah, cet. 1, 1421 H/2001 M), 509. Kitab alMaghazi Bab Ghazwh al-Hudaibyah hadis no. 4156.

${ }^{22}$ HR. Bukhari dalam Kitab Fardh al-Khams Bab ma kana an-Nabi SAW yu'thi al-muallafah qulubuhum no. 3145, Vol. 6, 290 dalam Fath al-Bari.

${ }^{23}$ Abu Bakar al-Kafy, Manhaj.... , 119 
al-Hushain bin Muhammad al-Anshary as-Salimy ra (hanya Isma'il bin Umayyah yang meriwayatkan hadis darinya), 'Umar bin Mahmud bin Jubair bin Muth'im (Al-Zuhri), Hammad bin Humaid al-Khurasany (hanya al-Bukhari yang meriwayatkan hadisnya), 'Ubaidillah bin Muhriz al-Kuufy (hanya Abu Nu'aim alFadhl bin Dukain), 'Atha' bin al-Hasan as-Suwaiyy (hanya Abu Ishaq AsSaibany), 'Amir bin Mus'ab (hanya Abdul Malik bin Juraij), Abu Muhammad alHadhramy (hanya Abu al-Wardi bin Tsumamah bin Hazn al-Qusyairy), Abu AnNashr al-Asady (hanya Khalifah bin Hushain). ${ }^{24}$

Walaupun Al-Bukhari mencantumkan periwayatan al-wuhdan ini, namun menurut penelitian Abu Bakar al-Kafy, al-Bukhari memiliki metode atau manhaj dalam menyikapi riwayat mereka: (1) Al-Bukhari tidak meriwayatkan dari perawi al-Wuhdan tersebut satu hadispun dalam keadaan tafarrud (menyendiri periwayatannya), (2) Al-Bukhari tidak bersandar secara total pada periwayatan mereka tetapi riwayat mereka disebutkan dalam konteks mutaba'ah dan istisyhad dengan cara mu'allaq (dipenggal sanadnya) dan tidak bersanad lengkap (ghair almusnadah), (3) Adapun hadis mereka yang cantumkan secara musnad sangatlah sedikit dengan posisi sebagai riwayat penyerta atau pendamping (maqrun) bagi riwayat pokok dari para perawi yang masyhur. Dengan demikian, menurut Abu Bakar al-Kafy, pendapat al-Hakim tidak tertolak secara mutlak sebagaimana pendapatnya al-Hazimy, al-Maqdisy, dll. Demikian pula tidak seluruhnya dapat diterima secara mutlak. Namun, dapat diterima dengan catatan (taqyid) sebagaimana pendapat as-Sakhawy dan Ibn Hajar; "Kalaupun pendapat itu tertolak dalam konteks periwayatan sebagian sahabat, namun hal itu diakui dalam konteks perawi setelah generasi sahabat. Sesungguhnya tidak ada dalam Kitab alBukhari, hadis pokok (utama) dari riwayat perawi yang hanya memiliki hanya satu murid saja." 25

Terkait dengan syarat kedua, bahwa al-Bukhari tidak mensyaratkan hadis-hadisnya bebas dari 'illah, Syaikh al-Mu'allimy berkomentar bahwa pendapat al-Hakim tidak tepat karena al-Bukhari dan Muslim tidaklah mengeluarkan hadis kecuali setelah diteliti dan dikaji bebas dari illah qadihah. Bahkan, menurutnya kekeliruan lebih jauh yang dilakukan al-Hakim dalam menetapkan syarat al-Bukhari dan Muslim dari sisi perawi adalah memperluas cakupan syarat al-Bukhari dan Muslim bukan hanya terbatas pada perawi yang memang tercatat dipakai oleh kedua itu, tetapi mencakup perawi-perawi lain yang dianggap selevel dalam hal ke-thiqah-annya dengan para perawi dalam kedua kitab tersebut. Di tambah lagi anggapan bahwa al-Bukhari maupun Muslim tidak mensyaratkan hadis bebas dari illah. Keduanya menjadi sebab utama mengapa banyak hadis-hadis ber-'illah dalam al-Mustadrak, bahkan berstatus munkar

\footnotetext{
${ }^{24}$ Ibid., 115-130

${ }^{25}$ Lihat Abu Bakar al-Kafy. Manhaj......, 115-130
} 
(sangat lemah karena bertentangan dengan riwayat lain yang lebih kuat) dan maudhu' (palsu). ${ }^{26}$

\section{Teori Ibn Thahir Al-Maqdisi (w. 507 H) dan Analisa Kritis Terhadapnya}

Muhammad bin Thahir Al-Maqdisi dalam kitabnya Syuruth al-Aimmah berpendapat bahwa syarat al-Bukhari dan Muslim adalah: "Keduanya mencantumkan (mengeluarkan) hadis-hadis yang disepakati ke-thiqah-an periwayatannya dalam hal 'adalah dan dhabth seluruh perawinya hingga sampai kepada sahabat yang masyhur." 27 Pendapat al-Maqdisi ini juga tidak diterima oleh sebagian ulama, di antaranya Muhammad bin Isma'il al-Amir al-Hasany alShan'any. Beliau menyatakan bahwa pendapat Ibn Thahir itu kurang tepat karena penetapan syarat al-Bukhari dan Muslim berupa perawi yang disepakati kethiqah-an periwayatannya adalah tidak benar. Muhammad bin Isma'il al-Shan'any beralasan dengan pen-dha'if -an oleh al-Nasa'i atas sejumlah perawi yang dipakai oleh al-Bukhari dan Muslim atau salah seorang di antara keduanya. Bahkan bukan hanya al-Nasa'i yang men-dha'if -kan sejumlah perawi tersebut, tetapi juga ada ulama al-Jarh wa at-Ta'dil lain yang menilai demikian. ${ }^{28}$

Al-Suyuthi membela al-Maqdisi dan menjawab sanggahan Ibn Amir asShan'any ini dengan menjelaskan bahwa maksud al-Maqdisi adalah perawi yang dicantumkan oleh al-Bukhari dan Muslim adalah perawi yang disepakati kethiqah-annya oleh ulama pada era kedua tersebut dan sebelum penyusunan kedua kitab sahih itu. Pen-dha'if-an oleh al-Nasa'i setelah munculnya kedua kitab itu tidaklah melemahkan status ke-thiqah-an perawi tersebut. Ibn Hajar menyatakan bahwa pendha 'if an oleh al-Nasa'i berasal dari ijtihadnya sendiri atau yang dikutip dari ulama sezaman dengannya bukan dari ulama generasi sebelumnya. ${ }^{29}$

Sementara itu, al-Hazimy mengakui bahwa tidak tepat jika al-Bukhari hanya mengeluarkan hadis dari perawi yang disepakati 'adalah-nya sebab hal tersebut terhalang oleh perbedaan pandangan setiap orang dalam menetapkan sebab-sebab yang berpengaruh langsung kepada ke-dha'if-an suatu riwayat. Di samping itu, terkadang al-Bukhari meninggalkan riwayat dari perawi yang thiqah dan lebih sahih lalu mengambil yang lebih rendah ke-thiqah-an dan kesahihannya disebabkan pertimbangan 'ali dan nazil-nya ${ }^{30}$ suatu sanad atau untuk menghindari pengulangan sanad yang sama dalam pencantuman hadis di berbagai tema bab terkait. $^{31}$

${ }^{26}$ Abdurrahman bin Yahya al-Mu'allimy, Al-Tankil bima Warada fi Ta'nib al-Kauthary min al-Abatil, Vol. 1, ed. Muhammad Nashiruddin al-Albany dan Muhammad Abd al-Razzaq Hamzah (Beirut: al-Maktab al-Islamy, cet. 2, 1407 H/1989 M), 457-458.

${ }^{27}$ Abul Fadl al-Maqdisi, Syuruth..., 17-18

${ }^{28}$ Muhammad bin Ismail as-Shan'any. Taudhih al- Afkar, 100-102

${ }^{29}$ Al-Suyuthi. Tadrib al-Rawy...,. Vol. 1, 172

${ }^{30}$ Panjang atau pendeknya jalur sanad sampaikepada Nabi SAW. Semakin pendek ('ali) suatu sanad semakin baik menurut ulama hadis.

${ }^{31}$ Lihat Al-Hazimy, Syuruth, 72-73 


\section{Teori Al-Hazimy (w. 584 H) dan Analisa Kritis Terhadapnya}

Al-Hazimy menyusun Kitab Syuruth al-Aimmah dan menyampaikan teorinya tentang syarat al-Bukhari dan Muslim. Menurut al-Hazimy, syarat alBukhari adalah mencantumkan hadis-hadis yang ittishal sanad oleh para perawi thiqah yang mutqin (teliti dan cermat) dan multazim (berguru dengan menyertainya dalam setiap keadaan) kepada orang yang diambil periwayatan hadis itu dalam waktu yang lama. Terkadang juga menggunakan periwayatan hadis dari perawi pada tingkatan yang lebih rendah dalam hal itqan dan lebih singkat masa mulazamah-nya. Syarat perawi yang lebih rendah dari itu dicantumkan oleh al-Bukhari hanya sebagai syawahid dan mutaba'ah. ${ }^{32}$ Lebih lanjut, al-Hazimy menjelaskan bahwa target utama al-Bukhari dalam seleksi hadisnya adalah riwayat dari para perawi terbaik dari level pertama dalam hal kethiqah-an, namun dalam kondisi tertentu al-Bukhari menurunkan standar kriterianya. Bahkan, al-Bukhari juga menampilkan hadis dari beberapa perawi yang dinilai ada unsur kedhoifannya. Akan tetapi tidak sampai sangat dha'if yang tertolak semua hadisnya. Apalagi, aspek kedha'if an sangat beragam dan para ulama berbeda dalam menetapkan penyebabnya. ${ }^{33}$

Pendapat al-Hazimy tentang ragam kualitas kesahihahan hadis dalam Sahih al-Bukhari selaras dengan hasil penelitian Ibn Hajar. Menurutnya hadishadis yang terdapat dalam kitab al-Jami' al-Shahih atau Sahih al-Bukhari dapat diklasifikasikan menjadi tiga (3) macam ; Pertama, hadis-hadis yang dicantumkan dengan sanad yang lengkap (musnad) dari al-Bukhari sampai (marfu') kepada Rasulullah SAW menggunakan lafal periwayatan (sighah) "haddatsana" atau yang setara. Hadis semacam ini kualitasnya sahih dan sesuai syarat sahihnya yang sejalan dengan penamaan kitabnya "al-Jami' al-Shahih". Kedua, hadis-hadis yang tidak termasuk dalam syarat sahih al-Bukhari walaupun kualitasnya layak untuk dijadikan hujjah. Hadis semacam ini dicantumkan dalam bentuk pengungkapan yang berbeda dengan kelompok pertama. Hadis semacam ini dicantumkan dalam bentuk Mu'allaqat. Ketiga, hadis-hadis yang tidak termasuk 'ala syarth alBukhari atau syarat dari hadis lainnya. Hadis semacam ini hanya dipakai sebagai penyempurna dalam bentuk kutipan secara lafal maupun makna untuk judul-judul bab dan pasal. Bahkan disebutkan untuk dijelaskan secara eksplisit maupun implisit kualitasnya sahih, Hasan atau dha'if . Hadis jenis pertama diposisikan sebagai hadis al-ushul (hadis pokok/utama) dan al-Mutaba'at al-musnadah (hadishadis penguat yang dicantumkan dengan sanad yang lengkap (musnad) dan

${ }^{32}$ Ibid.., 56-60. Nukilan dari ringkasan oleh Al-Suyuthi dalam Tadrib al-Rawy, Vol. 1, 175. Al-Hazimi memberi contoh lima tingkatan (thobaqot) senioritas dan kapabilitas muridmurid al-Zuhri. Al-Bukhari memilih tingkatan tertinggi perawi al-Zuhri sebagai perawi Sahih karena menghimpun kemampuan hafalan (hifdz), sifat itqan dan lamanya mulazamah (menyertai dan berguru) kpd al-Zuhri.

${ }^{33}$ Al-Hazimy. Syurut al- 'Aimmah as-Sittah, 70-71 
sampai kepada Rasulullah SAW (marfu'). Adapun hadis jenis kedua dan ketiga diposisikan sebagai tarajim. ${ }^{34}$

Namun klaim al-Hazimy bahwa pilihan ideal al-Bukhari atas riwayat dari para perawi terbaik dari level pertama dalam hal ke-thiqah-an perlu dikritisi. AlBukhari tidak mengharuskan seluruh hadis-hadis yang tercantum dalam kitabnya adalah hadis-hadis yang berkualitas di level tertinggi kesahihan hadis. Menurut Abdul Fatah Abu Ghuddah, realitias ini sangatlah jelas dalam Sahih al-Bukhari. ${ }^{35}$ Al-Bukhari bukan saja bermaksud untuk mencantumkan hadis-hadis yang sahih li dzatihi namun juga hadis yang sahih ligharihi dalam bentuk periwayatan dari perawi yang kurang dhabth-nya. ${ }^{36}$ Bahkan terdapat beberapa perawi dalam Shahih al-Bukhari yang dikritik oleh beberapa ulama hadis. Terdapat 80 orang perawi dalam Shahih al-Bukhari yang dikritik oleh al-Daraquthny. Keberadaan para perawi yang dikritik dalam kitab Sahih tersebut, menurut al-A'zamy, bukanlah kesalahan atau kekeliruan al-Bukhari dalam pensahihan hadis. Akan tetapi lantaran hadis-hadis tersebut tidak memenuhi standar atau syarat kesahihan yang tinggi yang biasanya digunakan oleh al-Bukhari. Penerimaan hadis-hadis mereka oleh al-Bukhari tentunya didasari dengan bukti-bukti yang menurutnya cukup terkait kejujuran penyampaian dan keakuratan riwayatnya. ${ }^{37}$

\section{Teori al-Nawawi (w. 676 H) dan Analisa Kritis Terhadapnya}

Al-Nawawi berpendapat bahwa yang dimaksud dengan syarat sahih alBukhari adalah rijal al-Isnad yang terdapat dalam kitab sahih-nya. Karena alBukhari tidak menjelaskan syarat sahihnya baik dalam kitab sahihnya maupun kitab lainnya. ${ }^{38}$ Menurut al-Iraqi, al-Nawawi merujuk pendapatnya kepada Ibn Shalah ketika berkomentar tentang al-Mustadrak al-Hakim. ${ }^{39}$ Pendapat alNawawi ini sejalan dengan praktek Ibn Daqiq al-'Ied dalam mengkritik suatu hadis dari al-Hakim yang diklaim 'ala syarth al-Bukhari misalnya, dengan mengajukan bukti bahwa dalam sanad hadis tersebut terdapat perawi yang tidak dipakai oleh al-Bukhari. Demikian pula praktek adz-Dzahabi dalam kitab Mukhtashor al-Mustadrak yang menilai ulang penshahihan 'ala syarth al-Bukhari atau Muslim atau kedua-duanya dengan merujuk bukti pada pemakaian perawi oleh al-Bukhari dan Muslim. ${ }^{40}$

\footnotetext{
${ }^{34}$ Ibn Hajar, Hadyu al-Sari, 6

${ }^{35}$ Komentarnya atas al-Muuqidzah dalam Al-Dhahaby, Al-Muqiz\}ah fi 'Ilm Must;alah alHadith (Beirut: Dar al-Basyair al-Islamiyyah, cet. 1, 1405 H), 80 dan 141.

${ }^{36}$ Ibnu Hajar. Al-Nukat, Vol. 1,...417

${ }^{37}$ M. Mustafa al-A'zamy. Studies in Hadits Methodology and Literature (tt, ttp, Revised edition), 92

${ }^{38}$ Al-Suyuthi, Tadrib...., Vol. 1,...175

39 Al-'Iraqy, al-Taqyid wa al-Idah Syarh Muqaddimah Ibn S\{olah, ed. Muhammad Raghib al-Tabbagh (ttp: tt). 29-30

${ }^{40}$ Namun, al-Iraqy mengkritik kesimpulan mereka karena kurang tepat.Sebab al-Hakim menyatakan bahwa rijal yang dipakai adalah yang "semisal atau setara" dengan al-Bukhari, bukan perawi yang dipakai oleh al-Bukhari sendiri. Lihat Al-Suyuthi, Tadrib...., Vol. 1, 175-176.
} 
Konsep syarat sahih al-Bukhari dengan hanya mengacu kepada perawi yang disebutkan oleh al-Bukhari dalam kitab sahihnya, memiliki kelemahan. Secara aplikasi, dengan perspektif semacam itu, al-Hakim dianggap tasahul dalam mengklaim kesahihan suatu hadis sebagai 'ala syarth asy-Syaikhani atau 'ala syarth al-Bukhari, dst. Menurut Abu Muadz, konsep syarat yang mengacu kepada perawi hanya dapat diberlakukan atas suatu hadis yang dihukumi sebagai hadis sahih 'ala syarth al-Bukhari-Muslim atau salah seorang di antara mereka berdua, jika telah memenuhi sejumlah ketentuan berikut: (1) Hendaklah para perawi dalam sanadnya adalah perawi yang juga dipakai oleh al-Bukhari dan/atau Muslim dalam masing-masing kitab sahihnya. Tidak cukup hanya dengan perawi lain yang ke-thiqah-annya dianggap sudah selevel dengan perawi al-Bukhari dan Muslim. Karena walaupun hadis mereka dapat dinilai sahih jika telah memenuhi syarat hadis sahih lainnya, tetap tidak bisa dinaikkan dalam klaim sebagai hadis sahih 'ala syarth al-Bukhari dan/atau Muslim. (2) Hendaknya para perawi hadis tersebut adalah perawi yang dicantumkan oleh al-Bukhari/Muslim sebagai ihtijaj (posisi hadis al-Ushul) bukan sebagai syawahid atau mutaba'at, ta'aliq atau maqrunan. (3) Hendaknya al-Bukhari dan Muslim berhujjah dengan seluruh perawi dalam sanadnya menurut jalur periwayatan yang sama dengan al-Bukhari dan/atau Muslim. Jika secara pribadi masing-masing perawi itu dipakai oleh alBukhari, sebagian lagi oleh Muslim. Maka dengan campuran semacam ini, hadis tidak bisa diklaim sebagai syarth al-Bukhari-Muslim atau 'alasyarth salah seorang dari keduanya. ${ }^{41}$

Ibn Hajar memberikan contoh seorang perawi bernama Sufyan bin Husain dari al-Zuhri. Kedua perawi tersebut memang dijadikan hujjah oleh Al-Bukhari maupun Muslim secara infirad (sendirian atau masing-masing perawi), tetapi keduanya tidak berhujjah dengan plot jalur riwayat Sufwan bin Husain dari AlZuhri. Karena sima'-nya Sufyan dari Al-Zuhri dha'if, berbeda dengan para syaikhnya yang lain. Maka, apabila ada hadis yang diriwayatkannya dari AlZuhri, tidak dapat diklaim sebagai 'ala sharth al-shaikhaini hanya lantaran karena Al-Bukhari maupun Muslim berhujjah dengan kedua perawi itu secara personal. Suatu hadis dapat dikatakan 'ala shart \{hima jika kedua masing-masing memakai perawi tersebut dalam satu plot rangkaian sanad (surah al-ijtima'). ${ }^{42}$

Menurut penelitian Ibrahim al-Abnasy $(725 \mathrm{H}-802 \mathrm{H})^{43}$ bahwa hadishadis yang kualitasnya di bawah syarat as-Sahih al-Bukhari jumlahnya sangat sedikit. Hadis-hadis tersebut terdapat dalam judul-judul Bab (tarajim al-Abwab). Hadis-hadis tersbut bukan termasuk dalam konteks penamaan kitab (al-Jami' alShahih al-Musnad Al-Sahih Al-Mukhtas\}ar min Umuri Rasulillah saw. Wa Sunanihi wa Ayyamihi) dan pengkhususan (takhsis) dari pernyataan al-Bukhari

\footnotetext{
${ }^{41}$ Lihat catatan kaki dalam al-Suyuthi, Tadrib...Vol, 1, 177

${ }^{42}$ Ibnu Hajar. Al-Nukat, Vol. 1, 314-315

${ }^{43}$ Ibrahim al-Abnasy. Asy-Syadza al-Fiyah..., 94
} 
yang menyatakan hanya mencantumkan hadis yang sahih. ${ }^{44}$ Dengan demikian, keberadaan hadis-hadis yang kurang dari standar al-Bukhari tidaklah mengurangi bobot sahih al-Bukhari dan pengakuan ulama terhadap tingginya syarat al-Bukhari karena prosentase hadis-hadis yang dikritik tidak signifikan dibandingkan hadishadis yang memenuhi standard tinggi syarth al-Bukhari.

\section{Merumuskan Syarat Sahih al-Bukhari}

Menurut penulis, secara teoritis, syarat sahih al-Bukhari sejalan dan konsisten dengan konsep syarat sahih yang dirumuskan oleh Ibn Shalah $^{45}$ dan disempurnakan oleh ulama lain seperti Nawawi dengan Ibn Hajar al-Asqalani. Melalui pengalamannya meneliti kitab Shahih al-Bukhari dan dengan keluasan ilmunya di berbagai cabang keilmuan hadis, menurut Ibnu Hajar al-Asqalany (w. $852 \mathrm{H})$, hadis sahih adalah:

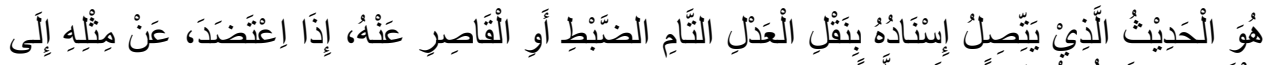

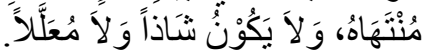

"Hadis yang bersambung sanadnya dengan periwayatan oleh perawi yang berkualitas adil dan sempurna ke-dhabit-annya atau kurang sempurna kedhobit-annya namun ada penguatnya, dari perawi sebelumnya dengan kualitas seperti itu, sampai akhir sanad, tanpa ada "illat dan syadz."46

Definisi tersebut memang cukup luas karena mencakup hadis marfu' dan selainnya dengan tanpa dibatasi dengan keadaannya yang “musnad" sebagaimana definisi pendahulunya, Ibn Shalah. Definisi tersebut juga memasukkan perawi yang kurang dhabit-nya. Dengan demikian, definisi di atas telah mencakup hadis sahih lighairihi yaitu hadis yang diriwayatkan oleh perawi yang kurang sempurna ke-dhabit-annya, namun memiliki penguat baik berupa syawahid maupun mutaba'at. Walaupun rumusan syarat sahih yang diajukan oleh Ibn Shalah maupun Ibn Hajar datang belakangan jauh setelah zaman al-Bukhari. Namun, konsep dan rumusan tersebut jelas lahir dari kajian mendalam terhadap metodologi (manhaj) para ulama hadis terdahulu (mutaqadimin) baik yang disampaikan secara ekspilisit dalam ungkapan mereka, maupun secara implisit dalam praktek penyaringan hadis dalam kitab-kitab mereka.

Adapun syarat kesahihan berupa Ittishal sanad, 'adalah ar-rawy, dan dhabth ar-rawy, adamu al-syadz dan 'adam al-illah merupakan kaedah atau syarat yang bersifat mayor yang pada umumnya disepakati dan dibakukan oleh ulama hadis. Sehingga manhaj ulama hadis dalam kriteria kesahihan hadis tidak

\footnotetext{
${ }^{44}$ Ibid., 94

${ }^{45}$ Menurut Ibn Shala $\left.>\mathrm{h}\right\}$, hadis sahih adalah

الحديث المسند الذي يتصل إسناده بنقل العدل الضابط عن العدل الضابط إلى منتهاه ولا يكون شاذا ولا معللا.

"Hadis yang musnad yang sanad-nya bersambung (ittishal) dengan proses transfer oleh perawi yang adil dan dhabit dari perawi yang adil dan dhabith sampai akhir sanad, tanpa ada syadz dan 'illat di dalamnya.", lihat Ibnu Shalah, 'Ulum al-H\}adith, 11-12

${ }^{46}$ Ibnu Hajar. Al-Nukat. Tahqiq Rabi’ al-Madkhaly, Vol. 1 (Riyadh: Dar ar-Rayah, cet. 3, 1415 H/1994 M), 416
} 
berbeda dalam tataran kaidah mayor. Perbedaan metodologis (manhaji) di antara para mukharrij hadis hanya dalam tataran kaidah minor yang merinci syarat-syarat mayor. Masing-masing ahli hadis terutama penyusun kitab hadis (mukharrij) memiliki beberapa perbedaan ijtihad dalam implementasi syarat minor tersebut. Rincian berupa syarat minor inilah yang perlu ditelusuri dan dirumuskan atas kitab Shahih al-Bukhari.

Mengingat beragamnya variasi kesahihan hadis sebagai konsekwesi proses periwayatan yang kompleks melewati rangkaian para perawi yang beragaman kualitas dan kuantitasnya dalam lintasan waktu yang cukup lama, maka menurut penulis, syarat kesahihan hadis-hadis al-Bukhari perlu dibedakan ada dua macam, yaitu syarth al-kamal yang merupakan standar tertinggi (al-had al-a'la) kesahihan hadis. Produknya adalah hadis-hadis di level shahih li dzatihi dan hasan li dzatihi. Mayoritas hadis-hadis al-Bukhari berada di level ini. Yaitu hadis-hadis yang musnad dan diposisikan sebagai hadis ushul (hadis utama dalam suatu bab dan biasanya disebutkan pertama kali) dan sebagian besar mutaba'at. Yang kedua adalah Syarth al-lazim yang merupakan standard minimum (al-h\}ad al-adna) kesahihan hadis. Produknya adalah hadis-hadis di level hasan li ghairihi. Dalam Shahih al-Bukhari terdapat dalam jumlahnya yang relatif sangat sedikit dalam mutaba'at dan di mu'allaqat. ${ }^{47}$

\section{Penutup}

Walaupun al-Bukhari tidak menjelaskan tentang syarat apa yang digunakannya dalam menilai kesahihan suatu hadis. Namun, sebagaimana para ulama hadis lainnya, jelas al-Bukhari menyaring hadis-hadis sahihnya dengan menggunakan parameter dan syarat kesahihan yang tertentu. Tentang apa persyaratan tersebut, menjadi hal yang didiskusikan bahkan diperdebatkan oleh para ulama hadis setelah masanya. Umum para ulama berikutnya seperti alMaqdisi, al-Hazimy, dan Al-Nawawi. mendiskusikan rumusan apa yang menjadi syarat al-Bukhari dalam menyeleksi hadis-hadis yang dicantumkannya dalam alJami' al-Shahih. Metode yang digunakan antara lain dengan cara metode induktif yaitu meneliti hadis-hadis al-Jami' al-Shahih untuk merumuskan kesimpulan umum syarat sahihnya. Ada pula dengan cara deduktif yaitu menggunakan teori syarat hadis sahih yang selama ini dikenal sebagai parameter untuk menilai keselarasannya dengan keadaan hadis-hadis dalam Shahih al-Bukhari.

${ }^{47}$ Al-Bukhari walaupun menjamin bahwa hadis-hadis yang dicantumkan dalam kitabnya tersebut adalah hadis-hadis yang berkualitas sahih. Namun, bukan berarti shahih li dzatihi. Menurut penelitian beberapa ulama hadis seperti Ibnu Hajar, tidak semua hadis-hadis dalam Shahih al-Bukhari berstatus shahih li dzatihi. Ada beberapa hadis yang kesahihannya karena adanya penguat atau disebut shahih li ghairihi. Bahkan - dalam kuantitas yang sangat sedikitterbukti ada penurunan standar kesahihan (misalnya hadis berkualitas hasan bahkan dha' if yang ringan pada hadis mu'allaq yang tamridh) dilakukan oleh al-Bukhari untuk jenis hadis-hadis tertentu antara lain hadis tentang fadha'il a'mal, hadis sirah dan maghazy. Hal ini, bukanlah hal yang aneh di kalangan ulama hadis. 


\section{Daftar Pustaka}

Al-'Iraqy, Zainuddin. al-Taqyid wa al-Idah Syarh Muqaddimah Ibn Solah, ed. Muhammad Raghib al-Tabbagh (ttp: tt).

Al-Abnasy, Ibrahim bin Musa bin Ayub. Asy-Syadz al-Fiyah min "Ulumil Hadis. Vol. 1, ed. Shalah Fathi Hilal. Riyadh: Maktabah Rusyd, Cet. 1: 1418 $\mathrm{H} / 1998 \mathrm{M}$.

Al-Bukhari, Muhammad bin Isma'il. al-Jami' al-Sahih al-Musnad al-Mukhtasar min H\{adith Rasulillah Sallallahu 'alaihi wa Sallam wa Sunanihi wa Ayyamihi, ed. Muhibuddin al-Khatib. Kairo: al-Maktabah al-Salafiyah, cet. $1,1400 \mathrm{H}$.

Al-Daruquthny, al-Ilzamat wa al-Tatabbu', ed. Muqbil bin Hady al-Wad'y Beirut: Dar al-Kutub al-'Ilmiyah, cet. 2, 1405 H/1985 M.

Al-Dhahaby, Al-Muqizah fi 'Ilm Mustalah al-Hadith. Beirut: Dar al-Basya>ir alIslamiyyah, cet. $1,1405 \mathrm{H}$.

Al-Hakim, Muhammad bin Abdillah al-Naisabury, al-Mustadrak 'ala Sahihain, Vol. 1, ed. Muqbil bin Hadi al-Wad'iy. Kairo: Dar al-Haramain, Cet. 1, 1417 H/1997 M.

, Al-Madkhal ila Kitab al-Iklil, ed. Fuad Abdul Mun'im Ahmad. Dar Dakwah : Iskandariyah.

Al-Kafy, Abubakar. Manhaj al-Imam al-Bukhary fi Tashih al-Ahadith wa Ta'liliha min Khilal al-Jami' al-Sahih. Beirut: Dar Ibn Hazm, cet. 1, 1421 $\mathrm{H} / 2000 \mathrm{H}$.

Al-Maqdisy, Abu al-Fad\}l Muhammad Tahir. Syurut al-Aimmah al-Sittah wa Yalihi Syurut al-Aimmah al-Khomsah li al-Hafiz Abubakar Musa alHazimy. Beirut: Dar al-Kutub al-'Ilmiyah, cet. 1, 1405 H/1984 M.

Al-Mu'allimy, Abdurrahman bin Yahya. Al-Tankil bima Warada fi Ta'nib alKauthary min al-Abatil, Vol. 1, ed. Muhammad Nashiruddin al-Albany dan Muhammad Abd al-Razzaq Hamzah. Beirut: al-Maktab al-Islamy, cet. 2, $1407 \mathrm{H} / 1989 \mathrm{M}$.

al-Nawawi, Yahya bin Syarf. Muqaddimah Syarh al-Nawawi 'ala Shahih Muslim, Vol. 1. Kairo: Al-Matba'ah al-Mishriyah bi al-Azhar, Cet. 1, 1347 H/1929 M.

Al-San'any, Muhammad bin Isma'il al-Amir. Tawdih al-Afkar li Ma'any Tanqih al-Anzar, ed. Muhammad Muhyidin 'Abd al-Hamid. al-Madinah alMunawwarah: al-Maktabah al-Salafiyyah, ttt.

Al-Sakhawy. Fath al-Mughits Syarh Alfiyah al-Hadith. Tahqiq: 'Abdul Karim alKhudhair dan Muhammad bin Abdullah Alu Fuhaid. Saudi: Maktabah Ushul al-Salaf, Cet.1, $1418 \mathrm{H}$.

Al-Suyuthi, Jalaluddin. Tadrib al-Rawy fi Syarh Taqrib an-Nawawy, Vol. 1, ed. Abu Mu'adz Thariq bin 'Audhillah bin Muhammad. Riyadh: Dar al'Ashimah, $1423 \mathrm{H}$.

Al-Syahir, Shalih Muhammad bin Shalih. Al-Ahadits allati yuriduha al-Imam alBukhari fi Tarajim al-Abwab wala yasrah bi kauniha ahadits, wa laisat 'ala syartihi. Tesis magister, Kuliyah Dakwah wa Ushuluddin, Qism Dirasat al-Ulya, program studi al-Kitab wa As-Sunah, Jami'ah Ummu alQuro', $1421 \mathrm{H}$.

Al-Tahhan, Mahmud. Taisir Mustalah al-Hadith. Iskandariyah: Markaz al-Huda li ad-Dirasat, $1415 \mathrm{H}$.

Al-Nukat. Tahqiq Rabi' al-Madkhaly, Vol. 1. Riyadh: Dar ar-Rayah, cet. 3, 1415 $\mathrm{H} / 1994 \mathrm{M}$.

Hadyu al-Sary Muqaddimah Fath al-Bary, ed. Syaikh 'Abd al-Qadir Syaibah alHamd. Riyadh: Maktabah al-Malik Fahd al-Watoniyyah, cet. 1, $1421 \mathrm{H} /$ $2001 \mathrm{M}$. 
Ibnu al-Atsir al-Jazary. Jami' al-Ushul min Ahadits ar-Rasul. Vol. 1, Tahqiq : Abdul Qadir al-Arnauth. Damaskus: ttp, cet 1, 1969 M.

Ibnu Hajar, al-Nukat 'ala Kitab Ibn Salah, vol. 1, ed. Dr. Rabi' bin Hady 'Umair Riyadh : Daral-Rayah, cet. 3, 1415 H/1994 M.

Ibnu Katsir, Al-Ba'its al-Hatsis Syarh Ikhtishar Ulum al-Hadits, ed. Syaikh Ahmad Syakir. Beirut: Dar al-Kutub al-'Ilmiyah, tt.

Ibnu Shalah, Abu 'Amr Utsman, 'Ulum al-Hadith (Muqaddimah Ibn Al-Salah), ed. Nuruddin 'Itr. Beirut: Dar al-Fikr, cet. 3, 1418 H.

Nuruddin, Manhaj al-Naqd fi 'Ulum al-hadith. Damaskus : Dar al-Fikr, Cet. 3, 1418 H/1997 M.

Syamsuddin Muhammad bin Ahmad. Siyar A'lam Nubala', Vol. 10. Beirut: Muassasah al-Risalah, cet. 9, 1413 H/1993 M.

Syamsuddin Muhammad bin Ahmad. Siyar A'lam Nubala', Vol. 12. Beirut: Muassasah al-Risalah, cet. 9, 1413 H/1993 M. 